\title{
Omeprazole prescriptions for older adults in health care units in Curitiba, Brazil: an analysis based on Beers Criteria
}

\section{Prescrições de omeprazol para idosos em unidades de saúde de Curitiba: análise segundo os Critérios de Beers}

\author{
Juliana Sambugaro ${ }^{a}$ (D), Hudson Prestes dos Santos ${ }^{b}$ (iD, \\ Linda Tieko Kakitani Morishita ${ }^{\text {(D) }}$, Alexandra Ingrid dos Santos Czepulab ${ }^{0}$
}

OBJECTIVE: To evaluate omeprazole prescriptions for older adults based on the Beers Criteria, with an analysis of indications and duration of use longer than eight weeks. METHODS: In this retrospective cross-sectional study, data were collected from the electronic medical records of older adults with an omeprazole prescription seen at two health care units in Curitiba, Brazil, between June and August 2019. Data were subjected to descriptive statistical analysis, Student $\mathrm{t}$ and $\chi^{2}$ tests. RESULTS: Medical records of 386 patients were analyzed, and 69.95\% were female. The mean age was 71 (SD, 8.15 ) years. Most patients had incomplete primary education (50.52\%) and income level ranging from one to two Brazilian minimum monthly wages (39.90\%). No indication for omeprazole prescription was found in $23.83 \%$ of medical records. Use longer than eight weeks was predominant for all indications in $96.60 \%$ of medical records. Duration of use more extended than the Beers Criteria recommendation was independent of $\operatorname{sex}(p=0.327)$, education $(p=0.805)$, and income level $(p=0.629)$. A relationship between polypharmacy and long-term drug use was demonstrated $(p<0.001)$. CONCLUSION: The results of this study suggest the need for periodic review of omeprazole prescriptions considering deprescribing when they appropriate. KEYWORDS: omeprazole; proton pump inhibitors; aged; medication errors.

OBJETIVO: Avaliar as prescrições de omeprazol para idosos de acordo com os Critérios de Beers, por meio das indicações e do tempo de uso do medicamento por período superior a oito semanas. METODOLOGIA: Estudo transversal, retrospectivo, no qual foram coletados dados dos prontuários eletrônicos de idosos com prescrição de omeprazol atendidos entre junho e agosto de 2019 em duas unidades de saúde em Curitiba. Os dados foram submetidos à análise estatística descritiva e aos testes t de Student e do $\chi^{2}$. RESULTADOS: Foram analisados prontuários de 386 usuários, sendo 69,95\% do sexo feminino. A média de idade foi de 71 anos (DP, 8,15). A maioria dos usuários tem ensino fundamental incompleto $(50,52 \%)$ e faixa de renda de um a dois salários mínimos (39,90\%). Não foi encontrada a indicação para a prescrição de omeprazol em 23,83\% dos prontuários. 0 uso por período superior a oito semanas foi predominante, para todas as indicações, em 96,60\% dos prontuários. Demonstrou-se que o tempo de uso superior ao recomendado nos Critérios de Beers independe do sexo $(p=0,327)$, da escolaridade $(p=0,805)$ e da faixa de renda $(p=0,629)$. Evidenciou-se a relação entre polifarmácia e uso do medicamento por períodos prolongados $(p<0,001)$. CONCLUSÃO: Os resultados deste estudo apontam para a necessidade de revisão periódica das prescrições de omeprazol, considerando-se a desprescrição quando apropriado.

PALAVRAS-CHAVE: omeprazol; inibidores da bomba de prótons; idosos; erros de medicação.

aCuritiba's City Council - Curitiba (PR), Brazil.

${ }^{\mathrm{b}}$ Faculdades Pequeno Príncipe - Curitiba (PR), Brazil.

Correspondence data

Juliana Sambugaro - Av. Cândido de Abreu, 817 - Centro Cívico - CEP: 80530908 - Curitiba (PR), Brasil. E-mail: juli.sambugaro@gmail.com Received on: 03/4/2021. Accepted on: 07/22/2021.

How to cite this article: Sambugaro J, Santos HP, Morishita LTK, Czepula AIS. Omeprazole prescriptions for older adults in health care units in Curitiba, Brazil: an analysis based on Beers Criteria. Geriatr Gerontol Aging. 20212021;15:e0210038. https://doi.org/10.53886/gga.e0210038 https://doi.org/10.53886/gga.e0210038 


\section{INTRODUCTION}

Proton pump inhibitors (PPIs) are prodrugs that, when activated under acid conditions, irreversibly inhibit pump molecules, suppressing up to $95.00 \%$ of gastric acid secretion for 24 to 48 hours. ${ }^{1}$ They are indicated for cases of gastroesophageal reflux disease (GERD), Zollinger-Ellison syndrome, treatment of Helicobacter pylori infection in conjunction with antibiotics, prevention of ulcers induced by nonsteroidal anti-inflammatory drugs (NSAIDs), and treatment of gastric or duodenal ulcers. ${ }^{2}$ Omeprazole is the most prescribed PPI in Brazil, as it has the lowest cost and is included in the Brazilian National List of Essential Medicines. ${ }^{3,4}$

PPIs are frequently prescribed for prolonged periods because they are considered safe and effective. However, some studies have shown long-term adverse effects, ${ }^{2}$ including hypomagnesemia, vitamin B12 deficiency, fracture risk (possibly related to reduced calcium absorption), cardiovascular risk (due to interaction with clopidogrel), Clostridioides difficile infection, pneumonia, fundic gland polyps, gastric cancer, and risk of chronic kidney disease. ${ }^{5,6}$ Also, a study associated regular PPI use for more than two years with an increased risk of type 2 diabetes. ${ }^{7}$ Older adults are particularly vulnerable to these effects. ${ }^{8}$

Older adults in Brazil accounted for $9.30 \%$ of the total population in 2019, with a projected increase to $13.60 \%$ by 2030 and $22.70 \%$ by $2050 .{ }^{9}$ Such demographic changes are accompanied by differences in the epidemiological profile, such as increased mortality from chronic diseases. ${ }^{10}$ Multiple drugs are usually prescribed for treating these diseases, which characterizes polypharmacy. ${ }^{11}$ Because of its complexity, polypharmacy may lead to treatment nonadherence and inappropriate medication use. Such factors, together with the physiological effects of aging, make older adults susceptible to adverse drug reactions and drug interactions. ${ }^{12}$

To assist in prescriptions for the older population, some criteria for potentially inappropriate medication use have been established, including the Beers Criteria, developed by the American Geriatrics Society, ${ }^{13}$ and the STOPP (Screening Tool of Older Persons' Potentially Inappropriate Prescriptions), ${ }^{14}$ developed in Ireland.

PPIs are potentially inappropriate medications for older adults. According to the Beers Criteria, their use should be avoided for longer than eight weeks, except in high-risk patients (eg,continuous NSAID use,esophagites, or pathological hypersecretory conditions) or in those with a demonstrated need for maintenance treatment. ${ }^{13}$ When indication is inadequate or when therapy duration exceeds the recommended period, deprescribing, a systematic process of identification and discontinuation of potentially inappropriate medications, should be considered to minimize polypharmacy. ${ }^{15}$

Therefore, this study aimed to evaluate omeprazole prescriptions for older adults seen at health care units in Curitiba, Paraná, Brazil, based on the Beers Criteria, with an analysis of indications and duration of use longer than eight weeks.

\section{METHODS}

In this retrospective cross-sectional study, data were collected from the electronic medical records of older adults with omeprazole prescriptions who were seen in June, July, and August 2019 at two randomly chosen municipal health care units in Curitiba. The sample was obtained from omeprazole activity reports available for the period. An electronic health management system (e-governe Saúde) was used to access reports and medical records.

Those aged 60 years or over, in accordance with the Brazilian Senior Citizen Statute, ${ }^{16}$ fully registered with the health care units, whose omeprazole prescriptions had been issued internally were included in the study. Data were collected by consulting electronic medical records and completing specific forms. The following were extracted:

1. sociodemographic data (sex, age, education, and income level);

2. indications for omeprazole use recorded in medical appointments;

3. duration of omeprazole use based on the history of drug prescription and dispensing in the past six years; and

4. presence of polypharmacy (yes or no) based on the history of prescribed drugs. Polypharmacy was defined as prescription of at least five drugs, a criterion adopted in the state of Paraná. ${ }^{10}$

Information collected from the medical records was entered in a Microsoft Office Excel 16 database. The data were tabulated with Sphinx Léxica, a quantitative/qualitative data analysis software, version 5.1.0.8. TIBCO Statistica, version 13.5.0.17, was used for statistical tests.

Descriptive analysis was used to characterize the sample, based on calculations of mean and frequency (absolute and relative). The Student t-test was used to ascertain whether there was a statistically significant difference between the mean ages of men and women. The $\chi^{2}$ test and, when applicable, Yates correction were used to assess associations between duration of omeprazole use and polypharmacy, sex, education, and income level. Significance level for all tests was set at 5\%.

This study was approved by the Research Ethics Committee of Curitiba's Municipal Health Department (CAAE certificate number 28680720.3.0000.0101).

\section{RESULTS}

The medical records of 456 patients seen at the two health care units were consulted, and 70 were excluded because registration was lost after death or because omeprazole prescription was issued externally. Thus, the final sample consisted of 386 medical 
records. In this sample, 270 (69.95\%) patients were female and $116(30.05 \%)$ were male. The age ranged from 60 to 100 years, with a mean age of 71 (SD, 8.15) years. No statistically significant difference was found between the means regarding $\operatorname{sex}(p=0.70)$.

In this study, as described in Table 1 , there was a predominance of patients with incomplete primary education (50.52\%) and income level ranging from one to two Brazilian minimum monthly wages (39.90\%). Polypharmacy was found in $61.14 \%$ of medical records. The $\chi^{2}$ test with Yates correction showed that the presence of polypharmacy was sex-independent $\left(\chi^{2}=2.14 ; \mathrm{p}=0.14\right)$.

Regarding duration of omeprazole use, most patients (49.74\%) were taking the drug for five years or over. The percentage was $54.81 \%$ in the female groupversus $37.93 \%$ in the male group, which shows a statistically significant difference $\left(\chi^{2}=13.63 ; \mathrm{p}=0.01\right)$.
In indications for use, the option "others" was the most described in the medical records (34.20\%). Upper gastrointestinal (GI) endoscopy reports, the most frequent findings being hiatal hernia and gastritis, as well as symptoms (dyspepsia, epigastric pain, pyrosis) that warranted an omeprazole prescription were included in this option. There was no indication for omeprazole prescription in $23.83 \%$ of medical records. The indication for gastric mucosal protection by NSAID use can be inferred in $21.24 \%$ of medical records with a prescription of acetylsalicylic acid (ASA) $100 \mathrm{mg}$ for prevention of cardiovascular events.

The Beers Criteria were used to assess duration of omeprazole use and indications. As shown in Table 2, use longer than eight weeks was predominantly identified for all indications in $96.60 \%$ of medical records.

Table 1. Distribution of sociodemographic and clinical variables in the older adult sample according to sex.

\begin{tabular}{|c|c|c|c|c|c|c|}
\hline \multirow{4}{*}{ Age } & \multicolumn{2}{|c|}{ Female } & \multicolumn{2}{|c|}{ Male } & \multicolumn{2}{|c|}{ Total } \\
\hline & mean & SD & mean & SD & mean & SD \\
\hline & 71.00 & 8.3 & 70.60 & 7.8 & 70.90 & 8.2 \\
\hline & $\mathrm{n}$ & $\%$ & $n$ & $\%$ & $n$ & $\%$ \\
\hline \multicolumn{7}{|l|}{ Education } \\
\hline Illiterate & 17 & 6.30 & 5 & 4.31 & 22 & 5.70 \\
\hline Incomplete primary school & 140 & 51.85 & 55 & 47.41 & 195 & 50.52 \\
\hline Complete primary school & 53 & 19.63 & 31 & 26.72 & 84 & 21.76 \\
\hline Incomplete secondary school & 20 & 7.41 & 8 & 6.90 & 28 & 7.25 \\
\hline Complete secondary school & 24 & 8.89 & 8 & 6.90 & 32 & 8.29 \\
\hline Incomplete tertiary school & 7 & 2.59 & 4 & 3.45 & 11 & 2.85 \\
\hline Complete tertiary school & 9 & 3.33 & 5 & 4.31 & 14 & 3.63 \\
\hline Total & 270 & 100 & 116 & 100 & 386 & 100 \\
\hline \multicolumn{7}{|l|}{ Income level } \\
\hline No income & 90 & 33.33 & 8 & 6.90 & 98 & 25.39 \\
\hline Up to 1 minimum monthly wage & 0 & 0 & 0 & 0 & 0 & 0 \\
\hline 1 - 2 minimum monthly wages & 111 & 41.11 & 43 & 37.07 & 154 & 39.90 \\
\hline $2-3$ minimum monthly wages & 24 & 8.89 & 30 & 25.86 & 54 & 13.99 \\
\hline 3 - 5 minimum monthly wages & 13 & 4.81 & 17 & 14.66 & 30 & 7.77 \\
\hline 5 - 10 minimum monthly wages & 2 & 0.74 & 8 & 6.90 & 10 & 2.59 \\
\hline No information & 30 & 11.11 & 10 & 8.62 & 40 & 10.36 \\
\hline Total & 270 & 100 & 116 & 100 & 386 & 100 \\
\hline \multicolumn{7}{|l|}{ Polypharmacy } \\
\hline Yes & 172 & 63.70 & 64 & 55.17 & 236 & 61.14 \\
\hline No & 98 & 36.30 & 52 & 44.83 & 150 & 38.86 \\
\hline Total & 270 & 100 & 116 & 100 & 386 & 100 \\
\hline \multicolumn{7}{|l|}{ Duration of omeprazole use } \\
\hline $0-2$ months & 7 & 2.59 & 6 & 5.17 & 13 & 3.37 \\
\hline $2-6$ months & 8 & 2.96 & 3 & 2.59 & 11 & 2.85 \\
\hline 6 months -1 year & 11 & 4.07 & 9 & 7.76 & 20 & 5.18 \\
\hline $1-2$ years & 37 & 13.70 & 14 & 12.07 & 51 & 13.21 \\
\hline $2-5$ years & 59 & 21.85 & 40 & 34.48 & 99 & 25.65 \\
\hline 5 years or over & 148 & 54.81 & 44 & 37.93 & 192 & 49.74 \\
\hline Total & 270 & 100 & 116 & 100 & 386 & 100 \\
\hline
\end{tabular}

Continue... 
Table 1. Continuation.

\begin{tabular}{|c|c|c|c|c|c|c|}
\hline \multirow{4}{*}{ Age } & \multicolumn{2}{|c|}{ Female } & \multicolumn{2}{|c|}{ Male } & \multicolumn{2}{|c|}{ Total } \\
\hline & mean & SD & mean & SD & mean & SD \\
\hline & 71.00 & 8.3 & 70.60 & 7.8 & 70.90 & 8.2 \\
\hline & $\mathrm{n}$ & $\%$ & $\mathbf{n}$ & $\%$ & $\mathrm{n}$ & $\%$ \\
\hline \multicolumn{7}{|l|}{ Indications for omeprazole use } \\
\hline Gastroesophageal reflux disease & 38 & 14.07 & 17 & 14.66 & 55 & 14.25 \\
\hline Gastric/duodenal ulcer & 2 & 0.74 & 5 & 4.31 & 7 & 1.81 \\
\hline Erosive esophagitis & 9 & 3.33 & 6 & 5.17 & 15 & 3.89 \\
\hline Helicobacter pylori infection & 2 & 0.74 & 1 & 0.86 & 3 & 0.78 \\
\hline Gastric mucosal protection (NSAID use)* & 50 & 18.52 & 32 & 27.59 & 82 & 21.24 \\
\hline Others $^{\dagger}$ & 93 & 34.44 & 39 & 33.62 & 132 & 34.20 \\
\hline No indication in the medical record & 76 & 28.15 & 16 & 13.79 & 92 & 23.83 \\
\hline Total & 270 & 100 & 116 & 100 & 386 & 100 \\
\hline
\end{tabular}

SD, standard deviation; NSAID, nonsteroidal anti-inflammatory drug; * patients with an acetylsalicylic acid 100 mg prescription; ${ }^{\dagger}$ other indications, such as reporting of symptoms and/or tests that warranted an omeprazole prescription.

Table 2. Duration of omeprazole use among older adults according to indications.

\begin{tabular}{|c|c|c|c|c|c|c|}
\hline \multirow{2}{*}{ Indication for use } & \multicolumn{2}{|c|}{ Up to eight weeks of use } & \multicolumn{2}{|c|}{ Over eight weeks of use } & \multicolumn{2}{|c|}{ Total } \\
\hline & $n$ & $\%$ & $n$ & $\%$ & $\mathrm{n}$ & $\%$ \\
\hline Gastroesophageal reflux disease & 1 & 7.70 & 54 & 14.50 & 55 & 14.20 \\
\hline Gastric/duodenal ulcer & 0 & 0 & 7 & 1.90 & 7 & 1.80 \\
\hline Erosive esophagitis & 1 & 7.70 & 14 & 3.80 & 15 & 3.90 \\
\hline Helicobacter pylori infection & 0 & 0 & 3 & 0.80 & 3 & 0.80 \\
\hline Gastric mucosal protection (NSAID use)* & 1 & 7.70 & 81 & 21.70 & 82 & 21.20 \\
\hline Others $^{\dagger}$ & 8 & 61.50 & 124 & 33.20 & 132 & 34.20 \\
\hline No indication in the medical record & 2 & 15.40 & 90 & 24.10 & 92 & 23.80 \\
\hline Total & 13 & 100 & 373 & 100 & 386 & 100 \\
\hline
\end{tabular}

NSAID, nonsteroidal anti-inflammatory drug; ${ }^{*}$ patients with an acetylsalicylic acid $100 \mathrm{mg}$ prescription; ${ }^{\dagger}$ other indications, such as reporting of symptoms and/or tests that warranted an omeprazole prescription.

Table 3. Association between sociodemographic variables and duration of omeprazole use.

\begin{tabular}{|c|c|c|c|c|}
\hline \multirow[t]{2}{*}{ Variable } & $\begin{array}{c}\text { Up to eight } \\
\text { weeks of use }\end{array}$ & $\begin{array}{c}\text { Over eight } \\
\text { weeks of use }\end{array}$ & Total & \multirow[t]{2}{*}{ p-value } \\
\hline & $n(\%)$ & $n(\%)$ & n (\%) & \\
\hline \multicolumn{5}{|l|}{ Sex } \\
\hline Female & 7 (2.59) & $263(97.41)$ & $270(100)$ & \multirow{3}{*}{0.32} \\
\hline Male & $6(5.17)$ & $110(94.83)$ & $116(100)$ & \\
\hline Total & 13 & 373 & 386 & \\
\hline \multicolumn{5}{|l|}{ Education* } \\
\hline Illiterate to primary education & $10(3.32)$ & $291(96.68)$ & $301(100)$ & \multirow{3}{*}{0.80} \\
\hline Secondary education to tertiary education & $3(3.53)$ & $82(96.47)$ & $85(100)$ & \\
\hline Total & 13 & 373 & 386 & \\
\hline \multicolumn{5}{|l|}{ Income level $^{*}$} \\
\hline$<5$ minimum monthly wages & $9(2.68)$ & $327(97.32)$ & $336(100)$ & \multirow{3}{*}{0.62} \\
\hline 5 - 10 minimum monthly wages & $0(0.00)$ & $10(100)$ & $10(100)$ & \\
\hline Total & 9 & 337 & 346 & \\
\hline
\end{tabular}

*Variables were grouped into two categories to enable the application of the $\chi^{2}$ test with Yates correction; accepted significance level was $p<0.05$.

Table 3 shows associations between duration of omeprazole use and sociodemographic variables. Duration of use longer than eight weeks, ie, exceeding the recommendation in the Beers Criteria, was independent of sex $(\mathrm{p}=0,32)$, education $(\mathrm{p}=0.80)$, and income level $(\mathrm{p}=0.62)$.

The relationship between polypharmacy and duration of omeprazole use is shown in Table 4. Most patients (91.90\%) 
Table 4. Relationship between polypharmacy and duration of omeprazole use.

\begin{tabular}{l|c|c|c} 
Duration of & \multicolumn{2}{|c|}{ Polypharmacy (yes) } & \multirow{2}{*}{ p-value } \\
\cline { 2 - 3 } omeprazole use & $\mathbf{n}$ & $\%$ & \\
Up to 1 year & 19 & 8.10 & \multirow{2}{*}{$<0.001^{*}$} \\
\hline Over 1 year & 217 & 91.90 & \multirow{2}{*}{ Total } \\
\hline
\end{tabular}

*Accepted significance level was $p<0.05$.

who were taking omeprazole for more than one year had prescriptions for at least five medications. There is a clear relationship between polypharmacy and long-term use of omeprazole $(\mathrm{p}<0.001)$.

\section{DISCUSSION}

The reported results show a higher prevalence of omeprazole prescriptions for female patients, similar to the results of previous studies. ${ }^{17-19}$ Long-term drug use was also significantly higher among women, as $54.81 \%$ took omeprazole for five years or over, which may be related to the higher prevalence of dyspepsia and greater demand for health care services by women compared with men. ${ }^{20,21}$

Income level ranging from one to two Brazilian minimum monthly wages and incomplete primary education were the most frequently reported data in medical records. This follows the pattern of Brazilian Institute of Geography and Statistics estimates for the state of Paraná. ${ }^{22}$

This study suggests a relationship between polypharmacy and long-term omeprazole use (over one year). The drug is commonly prescribed for gastric protection when the patient is taking multiple medications, regardless of its harmful potential. However, this indication is not approved, since not all drugs cause adverse effects on the gastric mucosa. ${ }^{23}$

Gastric protection is warranted when NSAIDs such as ASA are administered. The indication of low-dose ASA for secondary prevention of cardiovascular diseases is well established. However, it is associated with adverse GI effects, which may compromise treatment adherence. Therefore, co-therapy with a PPI, such as omeprazole, is the most accepted strategy to reduce ASA-related damage to the upper GI tract. ${ }^{24}$ In this study, co-therapy was found in $21.24 \%$ of medical records.

Similar to the findings of other studies, some omeprazole prescriptions had no reason described in the medical records and covered prolonged periods. ${ }^{18,19}$ Garrido and Hernández $z^{18}$ analyzed long-term PPI use in patients with a mean age of 70.9 years in a health care center in Spain. Omeprazole was the most used PPI (83.50\%). Over a third of patients (35.80\%) had no indication for use and $75.00 \%$ took it for more than five years.

A study in Brazil conducted by Hipólito et al. ${ }^{19}$ showed a relationship between longer omeprazole use, older age, and number of prescribed drugs. Most patients (84.30\%) took omeprazole for over six months, and $29.50 \%$ had no reason for use in the medical record.

In this study, the medical records in which no indication for omeprazole use was found were defined as failing to meet the Beers Criteria, especially because in $97.80 \%$ of the cases the drug was taken for more than eight weeks. Appropriately prescribed indications for a short period (GERD, Helicobacter pylori infection, and others) but extending for long periods, exceeding eight weeks, were also defined as failing to meet the criteria, as their value was potentially low. ${ }^{8}$

The assessment of risks and benefits of PPIs should be performed periodically, and deprescribing should be considered in the event of symptom remission or when therapy duration exceeds the recommended period. ${ }^{25}$ Some deprescribing strategies have been shown to be effective, including:

(a) gradual dose reduction before discontinuation to avoid a rebound effect;

(b) on-demand use, in which patients take a PPI once a day, if necessary, until symptoms disappear; and

(c) prescription of other drug classes (antacids, $\mathrm{H} 2$ receptor antagonists, and alginates) for managing occasional symptoms. ${ }^{26}$

In addition, lifestyle changes should be discussed individually in an attempt to reduce or fully discontinue PPIs. ${ }^{25}$

This study has some limitations, including the difficulty in finding complete information in the medical records, such as indications for omeprazole use. The lack of indication for use in the medical records does not exclude the possibility that the indication was based on unrecorded evidence. Also, there was a lack of up-to-date reports of upper GI endoscopy and other tests that warranted omeprazole use, as most results dated back to over two years.

\section{CONCLUSION}

This study evaluated omeprazole prescriptions in older adults and found that most of them do not meet the Beers Criteria, as they do not have an evidence-based indication or exceed the recommended treatment duration, which is 
consistent with previous studies. An association between polypharmacy and long-term omeprazole use was also demonstrated. Although more studies are required, the results suggest the need for periodic review of these prescriptions considering deprescribing when they are inappropriate.

\section{CONFLICTS OF INTEREST}

The authors declare no conflicts of interest.

\section{FUNDING}

None.

\section{AUTHORS' CONTRIBUTIONS}

JS: Conceptualization, Investigation, Methodology, Writing - original draft. HPS: Methodology, Data curation, Formal Analysis, Software. LTKM: Supervision. AISC: Supervision, Writing - review \& editing

\section{REFERENCES}

1. Wallace JL, Sharkey KA. Farmacoterapia da acidez gástrica, úlceras pépticas e doença do refluxo gastroesofágico. In: Brunton $L L$, Chabner BA, Knollmann BC. As bases farmacológicas da terapêutica de Goodman \& Gilman. 12th. ed. Porto Alegre: AMGH; 2012. p. 1310-1311.

2. Nehra AK, Alexander JA, Loftus CG, Nehra V. Proton pump inhibitors: review of emerging concerns. Mayo Clin Proc. 2018;93(2):240-6. https://doi.org/10.1016/j.mayocp.2017.10.022

3. Brasil. Ministério da Saúde. Secretaria de Ciência, Tecnologia e Insumos Estratégicos. Uso racional de medicamentos: temas selecionados. Brasília: Ministério da Saúde; 2012.

4. Brasil. Ministério da Saúde. Relação Nacional de Medicamentos Essenciais: RENAME 2020. Brasília: Ministério da Saúde; 2020.

5. Eusebi HL, Rabitti S, Artesani ML, Gelli D, Montagnani M, Zagari RM, et al. Proton pump inhibitors: risks of long-term use. J Gastroenterol Hepatol. 2017;32(7):1295-302. https://doi.org/10.1111/jgh.13737

6. Lazarus B, Chen Y, Wilson FP, Sang Y, Chang AR, Coresh J, et al. Proton pump inhibitor use and the risk of chronic kidney disease. JAMA Intern Med. 2016;176(2):238-46. https://doi.org/10.1001/ jamainternmed.2015.7193

7. Yuan J, He Q, Nguyen LH, Wong MCS, Huang J, Yu I, et al. Regular use of proton pump inhibitors and risk of type 2 diabetes: results from three prospective cohort studies. Gut. 2021;70(6):1070-7. https://doi.org/10.1136/gutjnl-2020-322557

8. Mafi JN, May FP, Kahn KL, Chong M, Corona E, Yang L, et al. Low-value proton pump inhibitor prescriptions among older adults at a large academic health system. J Am Geriatr Soc. 2019;67(12):2600-4. https://doi.org/10.1111/jgs.16117

9. United Nations. Department of Economic and Social Affairs. World population prospects 2019: Volume II: demographic profiles. New York: United Nations; 2019.

10. Paraná. Secretaria de Estado da Saúde do Paraná. Superintendência de Atenção à Saúde. Linha guia da saúde do idoso. Curitiba: SESA; 2018.

11. Hayes BD, Klein-Schwartz W, Barrueto Júnior F. Polypharmacy and the geriatric patient. Clin Geriatr Med. 2007;23(2):371-90. https:// doi.org/10.1016/j.cger.2007.01.002

12. Simonson W, Feinberg JL. Medication-related problems in the elderly: defining the issues and identifying solutions. Drugs Aging. 2005;22(7):55969. https://doi.org/10.2165/00002512-200522070-00002

13. By the 2019 American Geriatrics Society Beers Criteria ${ }^{\circledR}$ Update Expert Panel. American Geriatrics Society 2019 Updated AGS Beers Criteria ${ }^{\circledR}$ for Potentially Inappropriate Medication Use in Older Adults. J Am Geriatr Soc. 2019;67(4):674-94. https://doi. org/10.1111/jgs.15767

14. Gallagher P, O'Mahony D. STOPP (Screening Tool of Older Persons' potentially inappropriate Prescriptions): application to acutely il elderly patients and comparison with Beers' criteria. Age Ageing. 2008;37(6):673-9. https://doi.org/10.1093/ageing/afn197
15. Scott IA, Hilmer SN, Reeve E, Potter K, Le Couteur D, Rigby D, et al. Reducing inappropriate polypharmacy: the process of deprescribing. JAMA Intern Med. 2015;175(5):827-34. https://doi.org/10.1001/ jamainternmed.2015.0324

16. Brasil. Lei $n^{\circ} 10.741$, de 1 de outubro de 2003. Dispõe sobre o Estatuto do Idoso e dá outras providências. Brasília: Diário Oficial da União; 2003.

17. Emura-Vélez MH, Aguirre-Cardona M, Cardona-Echeverri DM, García-Maurno MA, García-Ospina DA, Gutiérrez-Osorio EA, et al. Prescripción-indicación de los inhibidores de la bomba de prótones: costo de la prescripción inadecuada en un primer nivel en Colombia. Acta Med Colomb [Internet] 2018 [Accessed in 2020 Oct 10];43(4). Available in: https://pesquisa.bvsalud.org/ portal/resource/pt/biblio-983704

18. Garrido MA, Hernández ISM. Adecuación y seguridad en el consumo crónico de inhibidores de la bomba de protones. Rev Clin Med Fam [Internet] 2017 [Accessed in 2020 Oct 10];10(2). Available in: https://scielo.isciii.es/scielo.php?script=sci_arttext\&pid=S1699$695 \times 2017000200070$

19. Hipólito P, Rocha BS, Oliveira FJAQ. Perfil de usuários com prescrição de omeprazol em uma Unidade Básica de Saúde do Sul do Brásil considerações sobre seu uso racional. Rev Bras Med Fam Comunidade. 2016;1 (38):1-10. https://doi.org/10.5712/rbmfc1 1(38)1153

20. Levorato CD, Mello LM, Silva AS, Nunes AA. Fatores associados à procura por serviços de saúde numa perspectiva relacional de gênero. Cien Saude Colet. 2014;19(4):1263-74. https://doi. org/10.1590/1413-81232014194.01242013

21. Ford AC, Marwaha A, Sood R, Moayyedi P. Global prevalence of, and risk factors for, uninvestigated dyspepsia: a meta-analysis. Gut. 2015;64(7):1049-57. https://doi.org/10.1136/gutjnl-2014-307843

22. Instituto Brasileiro de Geografia e Estatística. Síntese de indicadores sociais (SIS) 2019. Available from: https://www.ibge.gov.br/estatisticas/ sociais/saude/9221-sintese-de-indicadores-sociais.html. Accessed in Nov 14, 2020.

23. Gorostiaga JM, Orella EE, Hernáez BC. Análisis de la utilización de antiulcerosos inhibidores de la bomba de protones en el área de atención primaria de la comarca Araba. Rev Esp Salud Publica. 2018;92:e201808047. PMID: 30100604

24. García-Rayado G, Sostres C, Lanas A. Aspirin and omeprazole for secondary prevention of cardiovascular disease in patients at risk for aspirin-associated gastric ulcers. Expert Rev Clin Pharmacol. 2017;10(8):875-88. https://doi.org/10.1080/17512 433.2017.1324782

25. Pezeshkian S, Conway SE. Proton pump inhibitor use in older adults: long-term risks and steps for deprescribing. Consult Pharm. 2018;33(9):497-503. https://doi.org/10.4140/TCP.n.2018.497

26. Kim J, Blackett JW, Jodorkovsky D. Strategies for effective discontinuation of proton pump inhibitors. Curr Gastroenterol Rep. 2018;20(6):27. https://doi.org/10.1007/s11894-018-0632-y 